\title{
MODERN SPATIAL TRANSFORMATION IN HOLOSIIVSKYI DISTRICT OF KYIV
}

\author{
'Anatoliy MELNYCHUK, ${ }^{2}$ Svitlana KOVALCHUK \\ 1,2Taras Shevchenko National University of Kyiv, Ukraine \\ 'melan97@ukr.net
}

\begin{abstract}
The article examines trends and consequences of the urban space transformations in Holosiivskyi district of Kyiv caused by social transformations in the post-Soviet period. The authors focused attention on mapping the key changes that taken place at major historic-geographical sections characterizing formation and development of the territory comprising now a part of the urban district. The authors highlight the fact that changing of predominant spatial functions within the district was connected with the context of main functional (contextual) and spatial vectors of Kyiv development and by the corresponding change of spatial functions in the conditions of industrial and post-industrial periods. The authors developed a technique to determine the qualitative and quantitative parameters of the spatial transformation of the studied territory. Also, they determined the peculiarities of territorial functional changes in one of the centers of spatial development within the district - Lybidska square. There were determined the features and the quantitative and qualitative territorial differences in transformations of the functional structure of urban center under the influence of the core: shopping center "Ocean Plaza". The authors determined the number of key factors that have influenced and continue to influence the spatial transformations within this city center and function of territory belonging to the most and the least flexible in the context of the transformation of urban space.
\end{abstract}

Key words: urban space, the transformation of urban space, the functions of the territory, historic-geographical section.

UDC: 911.711 .55

\section{СУЧАСНІ ПРОСТОРОВІ ТРАНСФОРМАЦІЇ В ГОЛОСІЇВСЬКОМУ РАЙОНІ МІСТА КИЄВА}

\author{
'Анатолій МЕЛЬНИЧУК, ${ }^{2}$ Світлана КОВАЛЬЧУК \\ 1,2Київський начіональний університет імені Тараса Шевченка, Україна \\ 'melan97@ukr.net
}

\begin{abstract}
Анотація: У статті розглянуто напрями та наслідки трансформації міського простору Голосіївського району м. Київ, викликаної успільними перетвореннямиупострадянський період.Увагузосереджено навідображенні ключовихперетворень на основних історико-географічних зрізах, які характеризують формування та розвиток території, яка нині входить до складу міського район. Акцентовано на тому, що зміна переважаючих функцій території району була пов'язана контекстом головних функціональних (змістовних) та просторових векторів розвитку столиці України та відповідною зміною функцій території в умовах індустріального та постіндустріального періодів її розвитку. На основі розробленої методики визначено якісні та кількісні параметри трансформації просторудосліджуваної території, визначено особливості зміни функцій територіїв одному з центрів просторового розвитку району - Либідській площі. Визначено особливості, кількісні та якісні територіальні відміни у трансформаціях функціональної структури загальноміського центру під впливом ядра - ТРЦ "Оcean Plaza”. Виокремлено ряд основних чинників, які вплинули і продовжують впливати на трансформації території в межах даного міського центру та функції території які належать до найбільш та найменш гнучких у контексті трансформації міського простору.
\end{abstract}

Ключові слова: міський простір, трансформація міського простору, функції території, історико-географічний зріз.

УдК: 911.711 .55

Analysis of key researchs and publications starting a solution of problem

The publications of a significant number of scientists were devoted to various aspects of city development. Among them are the works of the national and foreign scientists such as K. Aksenov, D. Bogorad, E. Bondarchuk, I. Brade, D. Eckert, G. Lappo, V. Kolosov and others. Pecualiarities of the big city development and the transformation of urban space in modern world conditions were presented by a number of prominent urbanists like A. Ahyezera, S. Baumgartner, J. Jacobs, J. Boze-Garnier, J. Friedmann, S. Sassen, P. J. Taylor, M. Timberlake and others. The writings of Ukrainian scientists such as Y. Bilokin, O. Hladkyi, O. Drapikovskyi, I. Ivanova, V. Nudelman and others, in particular, disclose the issue of using urban territories on the example of Kyiv. There are not enough published issues about spatial features of

(C) А. Мельничук, С. Ковальчук urban territorial transformations in the historical part of Kyiv, in particular, about the transformation of its nuclear parts in the post-Soviet period.

The aim of the research is to explore the process of urban space transformation, to reflect the peculiarities of spatial development within the Holosiivskyi district of Kyiv on the main historic-geographical cross-sections, and to disclose qualitative and quantitative characteristics of spatial transformations of Lybidska square, one of the district spatial cores.

Presentation of the main material

Urban territories play prominent role in the development of modern society. These territories are characterized by a high level of complexity of their functional structure. In Kyiv city, as in the other capitals of the world, urban territories are characterized by a radical change and express temps of transformation (J. Friedmann, 1982; S. Sassen, 1991). Social transformations induce accelerating and deepening spatial transforma- 
tions in the largest cities of the former USSR. And thus, some functions of the territory are strengthened, while others disappear altogether owing to the development of the productive forces (Axenov K., Brade I., Bondarchuk E., 2006). This is especially clearly presented on the territories of the city centers influenced by certain cores that, in fact, forms these city centers.

Historic-geographical analysis has become one of the basic research methods of urban space transformation in Holosiivskyi district. In our case, distinguishing the historic-geographical cross-sections demands an indication of timeframe. During each cross-section we observed the following: community of Holosiivskyi district was at a certain development stage characterized by a certain level of spatial development, by a formed type of economic profile, production specialization, construction of residential neighborhoods and social infrastructure; formed sustainable correlation between predominant functions of territory of the district; a number of their manifestations, in a particular section, has its own specific structure.

Investigating irreversibility of the territorial functional changes in Holosiivskyi district, as the main criteria, made it possible for us to distinguish the following historic-geographical cross-sections.

The initial historic-geographical cross-section was marked by the development of separate parts of the future district as the city part. During the second half of the nineteenth century its northern areas were gradually integrated into the city. Training pavilions of Kyiv University were built in a vacant areas outside of Khreshchatyk according to the project of V. Beretti in 1834-1837. Over time, this empty locality was settled, comprising a new part of the city - Lybidska (historical Pankivschyna). In the 40 years of the XIX century University Boulevard was laid from the Khreshchatyk to the University (Fig. 1, 2).
In suburbs, in particular in Demiivka, as well as in other Kyiv suburbs (at that time Kyiv was a large provincial city of the European part of the Russian Empire), the majority of residential buildings were traditional huts, typical for Ukrainian village. In the 80th years of the nineteenth century a question of city communication network acutely raised, and therefore a new post office in Demiivka was opened in 1887.

At the second historic-geographical cross-section, marked by industrial transformation of the city (19001980-ies), the large industrial enterprises, appearing within the district, became the focuses of spatial growth [8, p.311].

The first administrative division (1921) resulted in creation of the Moscow district holding the area of Demiivka, being one of the Kyiv suburbs. The district includes such villages as Akademichne, Bahrynova Hora, Holosieve, Zhovtnevyi, Kytaeve, Konyk, Concha-Zaspa, Korchuvate, Novosilky, Pyrohovo, Feofania, Mysholovka, etc [12].

In Kurenivka, Demiivka, and Holosieve residents settled in the 4-5-storey houses with all communal facilities. The city center was the place for high-rise construction. The housing stock at the end of the 1-st five-year plan rose to 3.7 million sq. $\mathrm{m}$. At the same time, there was carried out construction for social, cultural, and municipal purposes. The construction of buildings for future Agricultural Academy started in Holosieve [9, p. 203]. There was continued recovery and reconstruction of logistics, roads, modernization of rolling stock. Since 1928 the main tram workshops started to produce new trams in addition to repairs. Individual districts and the city center were connected by direct communication lines: city routes tied Kurenivka and Podil, Demiivka and Khreshchatyk [9, p. 205].

Streets in some areas of the city were repaired; from 1926 to 1932 paved roads appeared on Saperno-

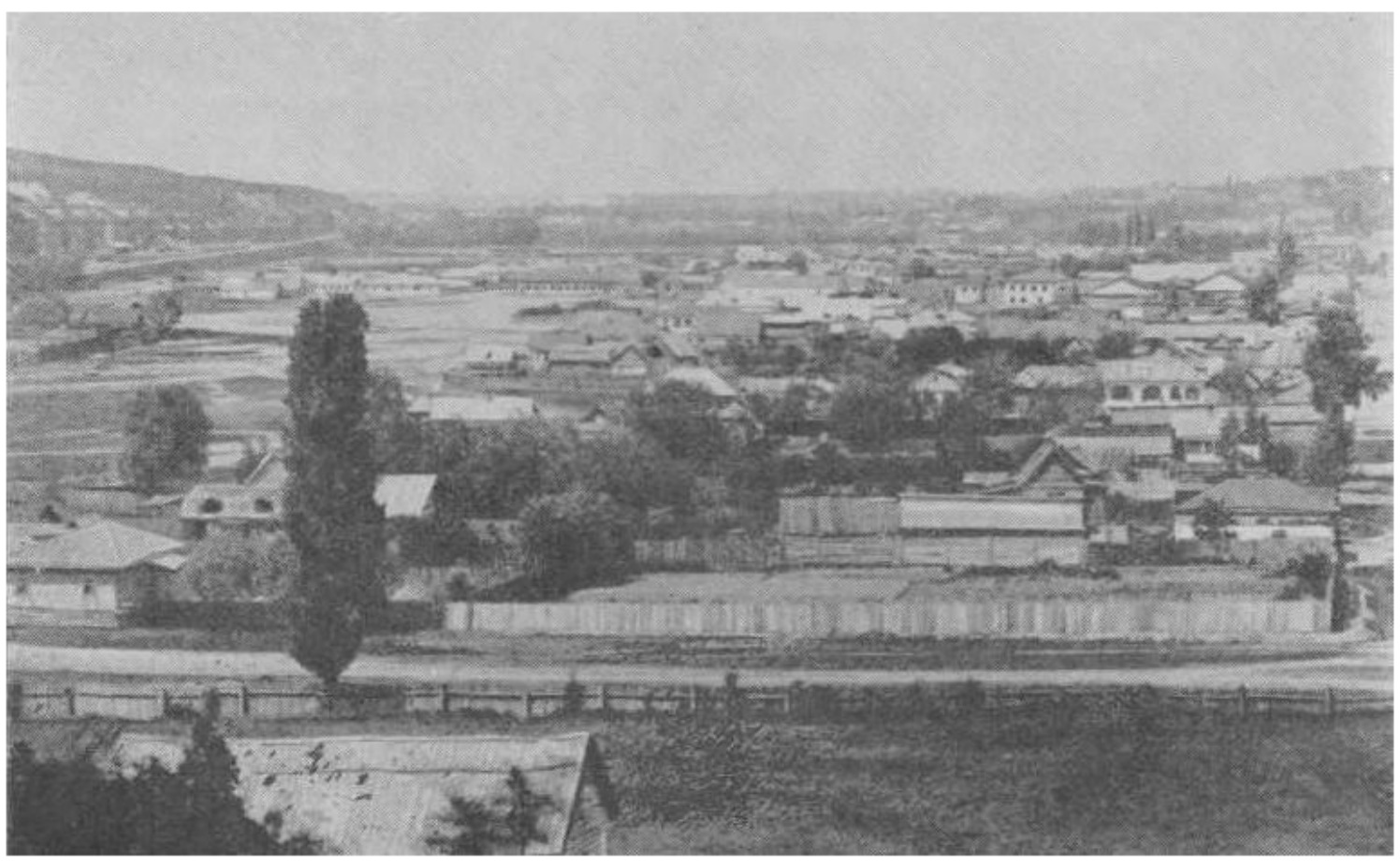

Fig. 1. Lybidska part of the city: "Novoe Stroenie", 19th century [8, p. 130] 
Slobidska street, in Protasiv Yar (mainly in new part of the city, in particular, in the northeastern part of modern Holosiivskyi district) [9, p.207]. Entrance ways for to the railway stations were equipped, particularly in Zhuliany.

Part of the district area periodically suffered from landslides and floods. Particular attention was paid to strengthening embankments of Lybid River and to areas such as Kurenivka and Protasiv Yar with a particularly high amount of ravines, slopes, and cliffs [9, p. 207]

Bozhenko Woodworking Factory and Marx Confectionery Factory were considerably reconstructed [9, p. 250]. Marx Confectionery Factory was founded in 1874 in Demiivka, former Kyiv suburb, as Demiivka Sugar Refinery (Fig. 3, 4).

The factory "Kyivkauchuk" was founded in 1930. By 1940, the territory of the city was significantly

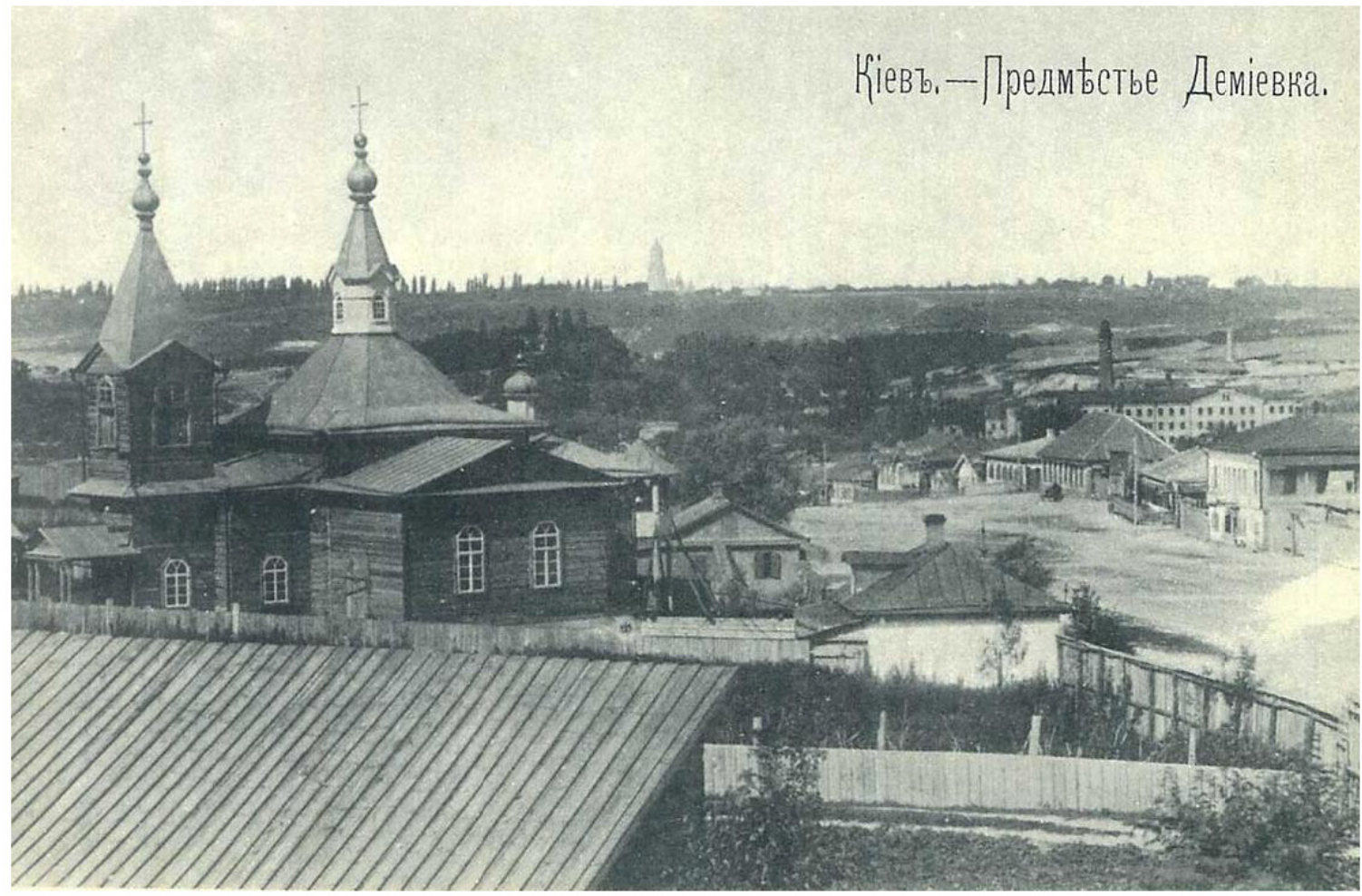

Fig. 2. Lybidska part of the city - "Novoe Stroenie", 19th century [8, p. 129]

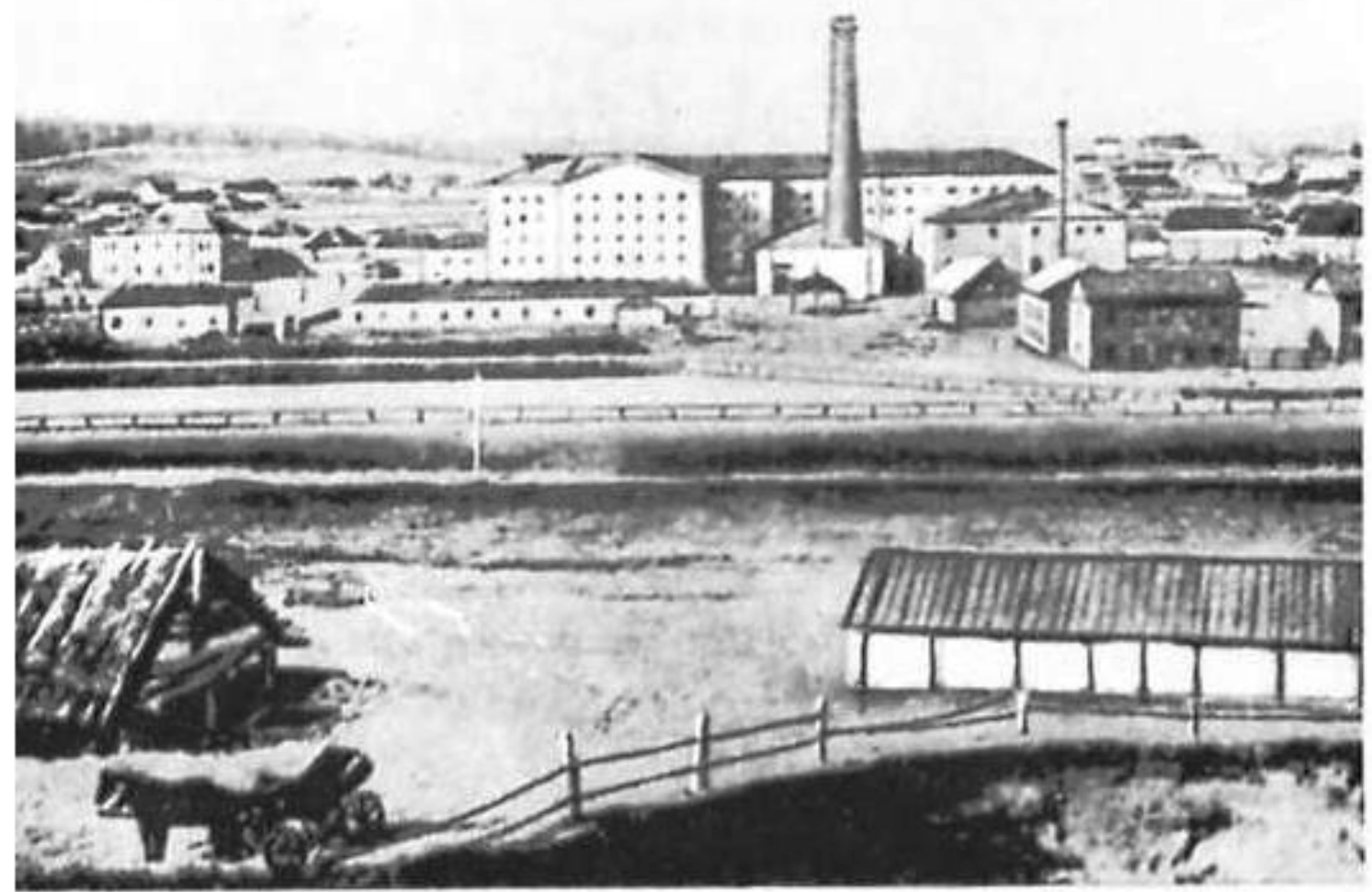

Fig. 3. Demiivka Sugar Refinery, 1874 [10] 
expanded, a range of industrial enterprises was reconstructed, therefore production potential significantly increased. Another famous large factories in Holosiivskyi district are worth mentioning the following: knitting factory "Kiyanka" (Fig. 5), founded in 1960 [14], and "Concrete Structures Plant" (Fig. 6), founded in 1956 for the implementation of housing and civil construction programs. At that time, it was the first major company in Kyiv producing precast concrete for large-house-building.

Direct routes for residents connecting Pushcha Vodytsia, Kurenivka and Zhytniy Rynok started to operate on September 1, 1938. These routes opened at 4:00 am. All city districts were connected with railway station by tram [9, p. 264]. There was continued construction of new artesian wells, pumping stations, and water pipes.

Kyiv acquired its modern shape, administrativeterritorial structure, and functional assignment of its parts (districts) during the last historic-geographical cross-section, marked by the transition of capital city to postindustrial phase (1990 - present day).

Holosiivskyi district was created in October 2001 as a result of administrative-territorial reform on the base of former Moscow district. Modern Holosiivskyi district is located in the south-west part of the Kyiv city.

Dnieper, Lybid, Vita, and Horihuvatka are rivers flowing through the territory of the district. Holosiivskyi district begins almost from Khreschatyk Street and

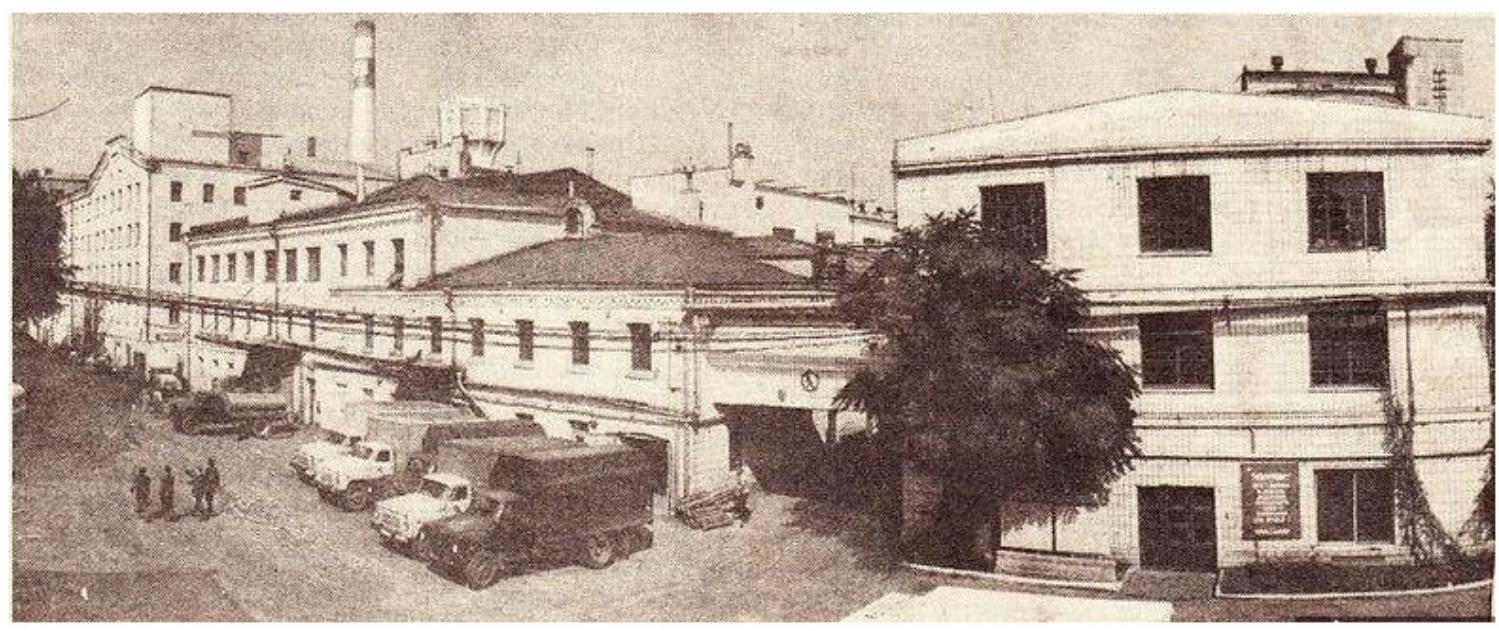

Fig. 4. Demiivka Sugar Refinery, 1975 [5]

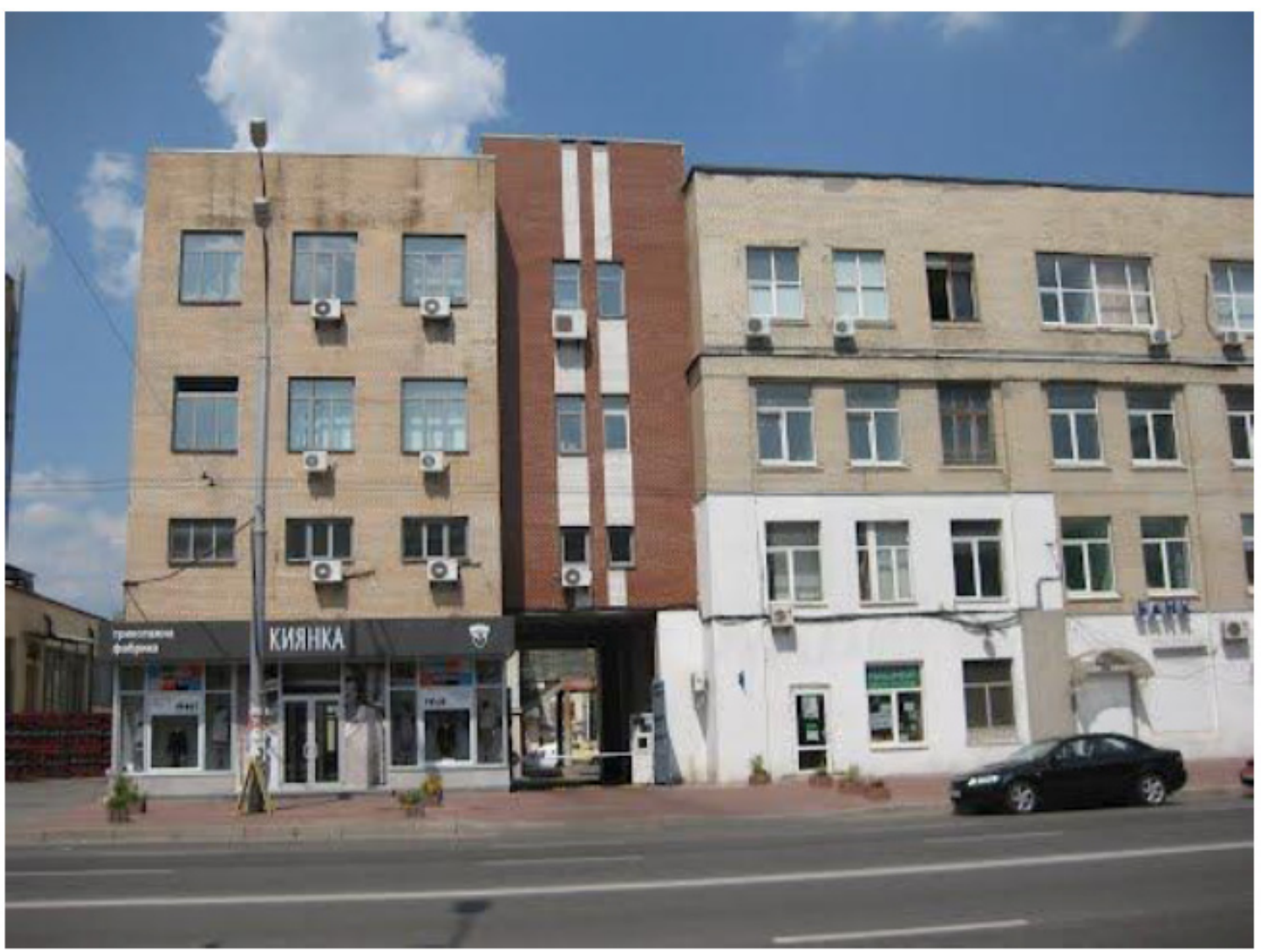

Fig. 5. Knitting factory “Kiyanka”, 2015 [Photo from personal archive of S. Kovalchuk] 
extends to the southern and western borders of Kyiv. In more detail, its borders lay from Kiltseva Doroga along the north-western city border, then going proximate to Lutsenko Street, Smolych Street, Moskovska Street, Moscovskyi Lane, Zhuliany village, Trutenka Street, along western margin of mechanical plant and margin of Vehicle Park \# 1, Kaisarova Street; Kirovogradska Street; border of Baikove Cemetery (inclusively), along railway to Baikova Street, along Lybid River to Ehrenburg Street, along north-eastern boundary of the railway, along Tolstoho Street; Chervonoarmiiska Street, Dzerzhynsky Square, Druzhby Narodiv Boulevard, railway, waterway of Dnieper River, and border of Kyiv to the Kiltseva Doroga. Thus, the district is the southern and southwestern gate of Kyiv.

Holosiivskyi district borders with Shevchenkivskyi, Solomenskyi, Pecherskyi and Darnytskyi (along the Dnieper River) districts of Kyiv City and KyivSviatoshynskyi, Obukhiv, and Boryspil districts of Kyiv Region.

Holosiivskyi district consists of the following historical areas: Pankivschyna, Predslavyne, Yamky, Saperna Slobidka, Baikova Hora, Zabaikivya, Demiivka, Shyrma, Tsymbaliv Yar, Dobryj Shlyah, Holosieve, Teremky, Feofaniya, Lysa Hora, Bahrynova Hora, Mysholovka, Samburky, Kytayeve, Pyrohiv, Tserkovschyna, Nyzhnia Telycka, Korchuvate, Vita, Vodnykiv Island.

The district has the largest area among the Kyiv districts: $156.36 \mathrm{sq} . \mathrm{km}$, accounting for $18.7 \%$ of the total Kyiv area. The length of the district: from north to south is $26.65 \mathrm{~km}$; from east to west $-15.75 \mathrm{~km}$. The population as of 01.01.2014 was 242.2 thousand of people, accounting for $8.4 \%$ of the total population of Kyiv.

Holosiivskyi forest, one of the oldest and largest in Europe, is a green treasury of Kyiv. This forest has unique flora and fauna. This amazing natural monument combines Feofania, Rylsky Park with an area of 140.9 hectares and, in particular, forest with an area of about 780 hectares. Green profile of Holosiivskyi forest is determined by more than 250 species of trees and shrubs. Its green outfit is diversified by nut species that have valuable hygienic properties and some unique centuriesold oaks are preserved in the area between Holosieve and Feofania.

Holosiivskyi forest is a priceless wealth of the city, its wellness zone, one of the favorite places of rest for Kyiv residents. A literary memorial museum of Maxim Rylsky is located at the eastern edge of the forest. The National Park "Holosiivskyi" was created in 2007. Holosiivska Street, Holosiivska Square, Holosiivskyi Lane, and Holosiivska subway station are located within the district [13].

The spatial transformations of urban territories depend on the nature of human activity, arising within the city territory historically or under the influence of other factors (environmental conditions, transport system, etc.). Since the population is a dynamic category, thus spatial transformations, directly or indirectly, constantly change the environment, adapting it to their own needs.

In cities, the places of high concentration of urban residents have a big impact on the fundamental func-

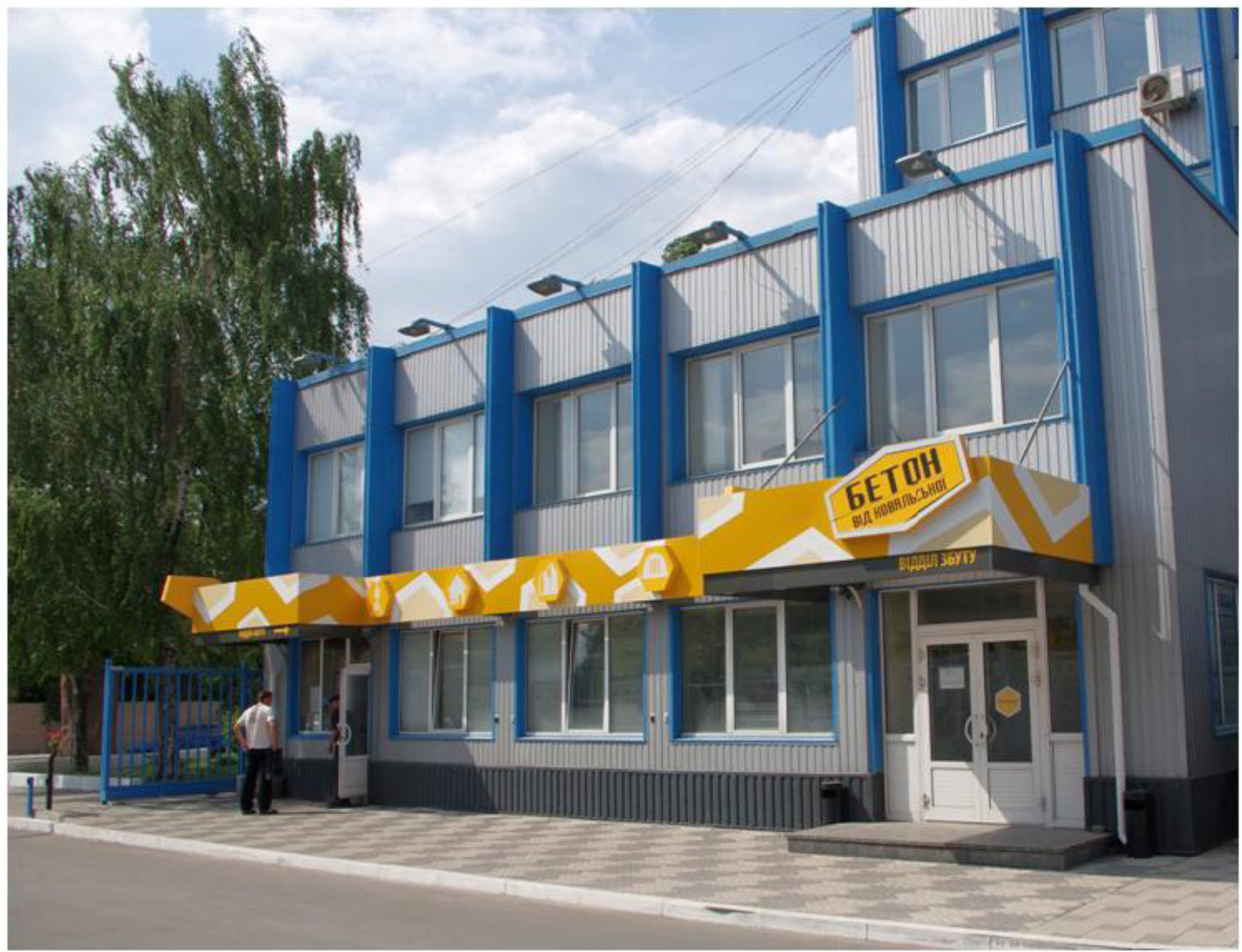

Fig. 6. PJSC "Kovalska Plant of Concrete Structures", 2015 [4] 
tional change or partial functional conversion of the parts of these cities. Accordingly, greater concentration and diversity of human activities have a great influence on the development of urban cores.

According to the old, geometric meaning of the term, city core includes the territory of the city limited by a circle or a circular shape holding the center (nucleus). However, today this approach to the definition of the city core is offset because in the present conditions there is a strong differentiation of cores (nuclei). Therefore, the nucleus of the city core is an object inducing the core to emerge and grow. Therefore, we can distinguish linear urban cores, developing along the line facilities (streets, waterways, etc.) and areal (or range) urban cores developing around the point objects (historic city center, shopping center, mall, etc.).

Formation of city centers directly affects the transformation of the surrounding adjacent territories due to changes in the basic functions that these territories perform. These changes are not uniform because different industries have unequal economic flexibility and ability to respond on external stimuli. One of the tasks at this stage of our research was to establish qualitative and quantitative characteristics of spatial transformations within Lybidska Square, being one of the cores within the studied territory. The transformation of the Square space was placed in the focus of attention due to placement there the shopping center "Ocean Plaza" (Fig. 7). It is located within Holosiivskyi district next to the Lybidska Subway Station. Our attention was directed on directly adjacent territories and Vasylkivska Street (its part within Holosiivskyi district) and Antonovycha Street.

The aim of this part of the research was to identify certain patterns and spatial differences in urban space transformations and to determine the predominance of certain functional zones formed under the influence of the shopping center "Ocean Plaza".

By the time of above-mentioned shopping center opening, Lybidska Square was a place of high concentration of city residents and guests of the capital. This was caused by the powerful traffic junction (a large number of routes had here final stop, Lybidska subway station was the ultimate station of the blue subway branch, here were located starting points of some intercity routes) and food market. But it did not cause the formation of a large urban center into force due to its mono-functionality and backwardness relatively to the needs of the modern big city. Instead, the newly built shopping center almost immediately began to change external (exposure) and internal (functional) structure of surrounding territories, gradually expanding the boundaries of influence.

Today the shopping center "Ocean Plaza" is a multifunctional formation. It combines the functions of rest (through entertainment institutions, cafes, restaurants, cinema, etc.), trade (here one can find wide range of food and as non-food goods for every taste and budget: from chewing gum, bread and milk to Hennessy and ham; from hairpins and socks to evening dresses, furs, and cars), business function (the center is the venue for business meetings), cultural, wellness and others.

Real changes of space we can see on the territories which are closest to the core of studied urban center. And almost all spheres of human activity fall under the influence of this core.

Analysis of the data, obtained during the field researches, made it possible to identify the following peculiarities of territorial functions and their changes within the studied territory.

Institutions of periodic demand dominate on Velyka Vasylkivska Street. Instead, institutions of everyday and

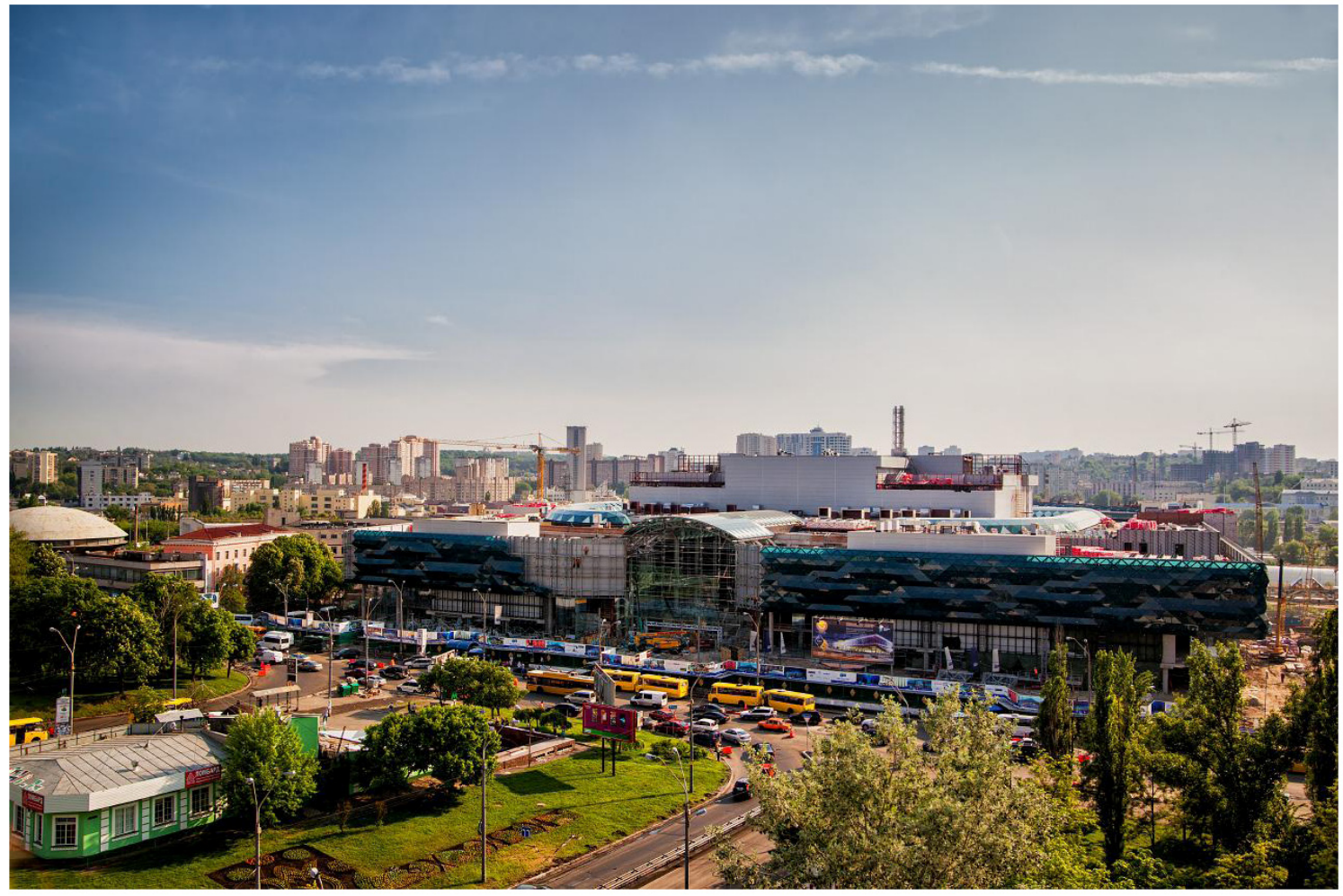

Fig. 7. Lybidska Square in Holosiivskyi district, Kyiv (view of the shopping center "Ocean Plaza") [3] 
Functional loading of the territory within Lybidska Square and adjacent territory

\begin{tabular}{|l|l|}
\hline Restaurants & \\
\hline Textile and footwear & \\
\hline Everyday life and machinery (or equipment) & \\
\hline Service centers & \\
\hline Medical service & \\
\hline Foodstuffs & \\
\hline Non-food goods and services & \\
\hline Building and repairing materials & \\
\hline Beauty, sports and recreation & \\
\hline Banking and other services & \\
\hline Polyfunctional & \\
\hline Educational and administrative management & \\
\hline Buildings that do only residential function & \\
\hline
\end{tabular}

\begin{tabular}{|c|c|c|c|}
\hline & $\begin{array}{c}\text { Velyka Vasylkivska } \\
\text { Street }\end{array}$ & Antonovycha Street & Lybidska square \\
\hline \multirow[t]{4}{*}{$\begin{array}{l}\text { Establishments of } \\
\text { everyday (mass) demand }\end{array}$} & $\begin{array}{l}\text { Interval Plaza shopping } \\
\text { center }\end{array}$ & \multirow{2}{*}{$\begin{array}{l}\text { Shopping center "Ocean } \\
\text { Plaza", shopping center } \\
\text { "Palladium City", } \\
\text { supermarkets "Furshet" }\end{array}$} & \multirow{2}{*}{$\begin{array}{l}\text { Stalls: Mr. Dog's, } \\
\text { Kharkiv's sausages, } \\
\text { products, cigarettes- } \\
\text { drinks "A8", } \\
\text { "Kulinichi" }\end{array}$} \\
\hline & $\begin{array}{l}\text { Grocery stores "Bohatyr" } \\
\text { "Eco Lavka"; stalls: Tea } \\
\text { and Coffee, Products }\end{array}$ & & \\
\hline & Pharmacy (2) & \multirow{2}{*}{$\begin{array}{l}\text { Pharmacy supermarket } \\
\text { "Aptekar" }\end{array}$} & Pharmacy "9-1-1" \\
\hline & $\begin{array}{c}\text { Pet Shop and Veterinary } \\
\text { Pharmacy }\end{array}$ & & $\begin{array}{l}\text { Hot Meat, Friendly } \\
\text { coffee, fast food } \\
\text { restaurant }\end{array}$ \\
\hline \multirow[t]{9}{*}{$\begin{array}{l}\text { Establishments of } \\
\text { periodic (sample) demand }\end{array}$} & $\begin{array}{l}\text { Textile, the shop of } \\
\text { footwear and accessories } \\
\text { «Intertop outlet》, a } \\
\text { clothing store Columbia }\end{array}$ & $\begin{array}{l}\text { Repair of clothing, atelier, } \\
\text { clothing store "Basler" }\end{array}$ & \multirow{5}{*}{$\begin{array}{l}\text { Store of shoes and } \\
\text { accessories } \\
\text { "Reasonable price" } \\
\text { store "Women's } \\
\text { lingerie and clothing" }\end{array}$} \\
\hline & $\begin{array}{l}\text { Beauty salons «Maija», } \\
\text { «Beauty lab» }\end{array}$ & $\begin{array}{c}\text { Beauty Studio BRUSH, } \\
\text { stall "Manicure", beauty } \\
\text { salon, beauty salon } \\
\text { "Jalila", sports center } \\
\text { "Success" }\end{array}$ & \\
\hline & Dentistry & Laboratory Synevo & \\
\hline & $\begin{array}{c}\text { Shops "Massage chairs", } \\
\text { "Budynok Ihrashok", stall } \\
\text { with flowers }\end{array}$ & stall with flowers & \\
\hline & $\begin{array}{c}\text { Bank Contract, Universal } \\
\text { Bank, Piraeus bank, Delta } \\
\text { Bank, Raiffeisen Bank } \\
\text { Aval, the bank FUIB, } \\
\text { Otpbank, Oschadbank } \\
\end{array}$ & \multirow[t]{2}{*}{$\begin{array}{c}\text { "Nova Poshta" } \\
\text { department №82, Unex } \\
\text { Bank, Ukreximbank, } \\
\text { Bank Financial Initiative, } \\
\text { PrivatBank, UkrSibbank }\end{array}$} & \\
\hline & House wallpaper Maestro & & \multirow{4}{*}{$\begin{array}{l}\text { Barber "Posto } \\
\text { perukarnya" }\end{array}$} \\
\hline & $\begin{array}{c}\text { Customer service center } \\
\text { Lenovo, iService and } \\
\text { iStore } \\
\end{array}$ & $\begin{array}{l}\text { Library, State Scientific- } \\
\text { Technical Library }\end{array}$ & \\
\hline & House of music & & \\
\hline & $\begin{array}{c}\text { Cafe-bar Hooligans food } \\
\text { project, cafe, L'KAFA } \\
\text { cafe }\end{array}$ & Pub "Beer shtab" & \\
\hline \multirow[t]{4}{*}{$\begin{array}{l}\text { Establishments of } \\
\text { episodic (sample) demand }\end{array}$} & $\begin{array}{l}\text { VIP gifts "Frank Meisler", } \\
\text { gallery of pearls } \\
\text { "Yamagiwa" }\end{array}$ & $\begin{array}{l}\text { Online shop "Zakazik", } \\
\text { shop of handmade carpets } \\
\text { "Lotus", furniture and } \\
\text { accessories, salon audio, } \\
\text { video and high-tech }\end{array}$ & \multirow[t]{4}{*}{$\begin{array}{l}\text { The lottery "National } \\
\text { Lottery", "Partner" } \\
\text { Lombard, "Credit } \\
\text { Cafe" }\end{array}$} \\
\hline & Sauna & $\begin{array}{c}\text { Travel agency "Poehali s } \\
\text { nami" }\end{array}$ & \\
\hline & $\begin{array}{l}\text { Warehouse store } \\
\text { "Budmax", building } \\
\text { materials }\end{array}$ & $\begin{array}{c}\text { Shops "Parquet", "Novyi } \\
\text { mir" (doors) }\end{array}$ & \\
\hline & Notary (2), pawn shop & $\begin{array}{c}\text { The insurance company } \\
\text { UNIQA, fly Vista, Utair } \\
\text { Ukraine, PRO100 } \\
\text { Insurance, Bureau of } \\
\text { Ukraine forensic experts, } \\
\text { League of taxpayers, } \\
\text { Tehnoskar / Zolotoskar / } \\
\text { Lombard Oscar }\end{array}$ & \\
\hline
\end{tabular}


episodical demand are presented almost in equal numbers, with a slight advantage of the latter. Most establishments of selective demand located remotely from the urban center core. This can be explained by two factors: the presence of large competitors with similar products in the core of the center that pushes them to the periphery and at the same time attraction of them to the historic center of the city, where demand is increasing.

Antonovycha Street also concentrates mostly establishments of periodic demand, but there don't lag the institutions of episodic demand too. As for the everyday demand, there are a very small number of these institutions. In general, all of them are fairly dispersed through the territory, which makes it impossible to determine a relationship between object and demand.

Food and fast food sales points, related to the everyday demand are brightly presented within the Lybidska Square. Also, there are establishments of periodic and episodic demand (the latter represented in the least). This can be explained by functional features of this territory, its small size and geographic location relative to the core of the city center.

To determine the spatial features of the commercialservice establishments' location within the city center are not enough to allocate it according to "type of demand" so we made a classification of the establishments by functional purpose (Table. 1) according to defined functional categories.

Further, in this research we divided the territory of the city center influence into functional zones (Fig. 8).

The state structures are located on both sides from the shopping center "Ocean Plaza" along the Antonovycha street (State Scientific and Technical Library of Ukraine is located at $185 \mathrm{~m}$ to the south, and State Consumer Inspectorate of Ukraine is located at the $68 \mathrm{~m}$ to the north). Moving to the east, food and fast food sales points concentrate on Lybidska Square with numerical superiority over other establishments, but there are also objects from categories of medical service (pharmacy), beauty, sports and recreation, textile industry and footwear. Passing the square, on Velyka Vasylkivska Street, is located a zone of textile industry and footwear that stretches from south to north over a distance of 155 meters, and multifunctional zone that lies within a building \# 143 and has a length of $102 \mathrm{~m}$, and the average distance from the core to the above-mentioned zones is $112 \mathrm{~m}$.

On Velyka Vasylkivska Street, to the north from the shopping center "Ocean Plaza" in the side of the historic center are located following functional zones:

1) Multifunctional: 3-4 min. walking distance, a length of $124 \mathrm{~m}$, includes buildings \# 136 and \# 134 with recreation establishments, health, education, banking and other services, sale of building materials, sale of consumer goods and services;

2) Banking and other legal and financial services: in 5-6 min. walking distance, a length of $227 \mathrm{~m}$, within buildings \# 132 and \# 130.

3) Educational and administrative management: in 8 min. walking distance, a length of 117 meters, within a building \# 128;

4) Restaurants: 9 min. walking distance, a length 38 $\mathrm{m}$, within a building \# 126;
5) Beauty, sports, and leisure: in 11 min. walking distance, within a building \# 124;

6) Food: in 11 min. walking distance;

7) Textiles industry and footwear: in 11- $12 \mathrm{~min}$. walking distance, a length of $30 \mathrm{~m}$, within a building \# 122;

8) Banking and other legal-financial services: in 13-14 min. walking distance, a length of $169 \mathrm{~m}$, within buildings \# 120, \# 118, partly \# 116;

9) Restaurants: in 13 min. walking distance, a length $23.5 \mathrm{~m}$, within a building \# 116.

On Antonovycha street, to north from the shopping center "Ocean Plaza" in the side of the historic center are located following functional zones:

1) Multifunctional: 2-5 min. walking distance, a length of $228 \mathrm{~m}$ on both sides of the street, and includes buildings \# 169, \# 172, \# 165 and \# 170, with establishments of everyday life and machinery, building materials, food, and non-food product sales, medical service, banking and other legal financial services, administrativemanagement institutions;

2) Non-food products and services: in $5 \mathrm{~min}$. walking distance, length $55 \mathrm{~m}$, on the right side of the street, within the building \# 157 and in $11 \mathrm{~min}$. walking distance, length $23 \mathrm{~m}$, within a building \# 138 and adjacent territories;

3) Banking and other legal financial services: in 11 min. walking distance, a length of $58 \mathrm{~m}$ on both sides of the street, within buildings \# 162 and \# 155.

4) Educational and administrative: in $8 \mathrm{~min}$. walking distance, a length of $111 \mathrm{~m}$ on the right side of the street (school \# 130);

5) Everyday life and machinery: in 7 min. walking distance, length $47 \mathrm{~m}$ on the left side of the street, within the building \# 158 and 9 min. walking distance, length $51 \mathrm{~m}$, within a building \# 152;

6) Beauty, sports and recreation: in 8 min. walking distance, length $33 \mathrm{~m}$, within a building \# 156;

7) Textile and shoes: in 9 min. walking distance, a length of $65 \mathrm{~m}$ on the left side of the street, within a building \# 140;

8) Banking and other legal-financial services: in 9-10 min. walking distance, a length of $105 \mathrm{~m}$ on the right side of the street, within a building \# 127;

9) Restaurants: in $11 \mathrm{~min}$. walking distance, length $43 \mathrm{~m}$ on the right side of the street, within a building \# 125;

10) Educational and administrative: $12 \mathrm{~min}$. walking distance, a length of 65 meters on the left side of the street (school №37);

11) Banking and other legal-financial services: in 12 min. walking distance, length $27 \mathrm{~m}$ on the right side of the street, within a building \# 123.

Thus, analyzing the given data, we can highlight certain features of functional zoning of the urban center territory. First, there are clearly distinguished multifunctional zones within the territories of most and least close to the core of the studied urban center. The concentration and variety of functional zones near the core is the obvious thing because there are concentrated the largest number of people who are potential visitor or customer, and it causes increasing the desire of owners of establishments of different type and purpose to work 

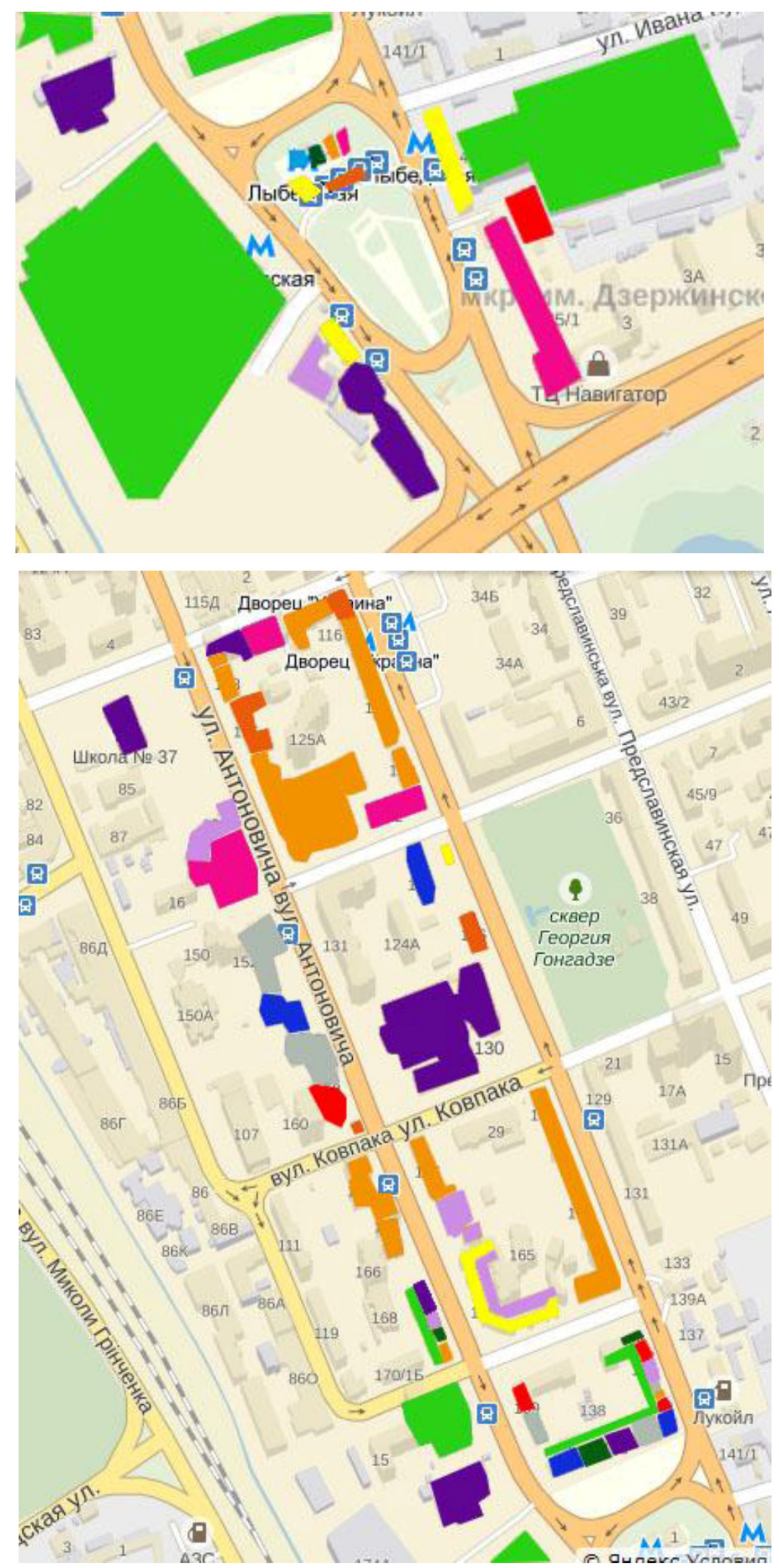

Fig. 8. Features of territorial functioning after construction of the shopping center "Ocean Plaza" on Lybidska Square (legend as for the Table 1) 
on this territory. Multifunctionality of remote areas at a glance is an abnormal phenomenon, but in this situation it is because this part is influenced by another urban center, namely the historic center, which causes such a feature. Functioning of educational and administrativemanagement establishments on the closest territories can be justified in terms of historical factors.

Secondly, there is a considerable presence of a large number of banks and institutions to provide legal and financial services. And it is also oriented to a large number of populations that is economically active and constantly deal with legal financial transactions. Non-food stores and service establishments have here a clear advantage. This pattern is common to the central parts of the city and this makes it possible to talk about the integration of the researched part of the city to the concept of "center", although until recently it was a peripheral part of the city. Also, the lack of a large number of grocery stores here can be justified by the presence of large supermarkets "Auchan", "Furshet" that fully cover the needs of the residents of this district.

Now we look at the change of quantitative and qualitative indicators of territorial transformations over time. The Lybidska square got a first place by the amount of establishments that in some way were transformed. On this square, there were changed 16 objects. Clearly, at the photos taken before construction of shopping center "Ocean Plaza" the square is almost empty. Each of the following spatial segments has eight modified objects: Velyka Vasylkivska St. from the intersection with Liubchenka St. to the intersection with Kovpaka St. and Antonovycha St. (buildings \# 131, 155, and 157). The slightest change (one object) have segments of Antonovycha St. (buildings \# 123-127), Antonovycha St. (from the intersection with Telmana St., buildings \# 130-136) and Antonovycha St. (to the intersection with Kovpaka St.; buildings \# 152-158). Absolutely not changed: Velyka Vasylkyvska St. (building \# 128) and Antonovycha St. (buildings \# 172-174).

If we consider the changes in percentage terms, then:

a) the most altered spaces: Lybidska square, Velyka Vasylkivska St. (buildings \# 126-124) and Antonovycha St. (from the shopping center "Ocean Plaza" to the intersection with Druzhby Narodiv Blvd.);

b) the least altered: Antonovycha St. (from the intersection with Telmana St., buildings \# 130-136), Antonovycha St. (to the intersection with Kovpaka St.; buildings \# 152-158).

c) unchanged: Velyka Vasylkivska St. (buildings \# 128) and Antonovycha St. (buildings \# 172-174).

In order to assess the spatial change in qualitative terms we divided all transformed establishments according to four indicators. Thus, the first category is the "percentage change of the first rank". This means that there was a substitution of one establishment to another without functional change. For this indicator, most changes were on territories: Antonovycha St. (from the shopping center "Ocean Plaza" to the intersection with Druzhby Narodiv Blvd), Velyka Vasylkivska St. (from the intersection with Kovpaka St. to the intersection with Telmana St.), Antonovycha St. (buildings \# 152-
174), Velyka Vasylkivska St. (from the building \# 136 to the intersection with Kovpaka St.). In particular, food shops (stalls) replaced by similar sale points, as well as banks and establishments with legal financial directions of services. This modification was provoked mainly by economic factors associated with changes of rent and wages, closing banks in Ukraine, a decrease of branch offices etc.

The second category includes establishments that have undergone major changes (II). They accounted for the largest share on the Antonovycha St., from the building \# 155 to Lybidska square, and from the intersection with Telmana St. to the building \# 140. They include cafes, grocery stores, and slot machines replaced by the nonfood shops and services establishments.

The following two categories are the "percentage of closed establishments" and "percentage of newly opened establishments". The greatest reductions were observed on the part of Antonovycha St, from the intersection with Telmana St. to the building \# 155. However, it should be noted that in this area the percentage of newly opened establishments is equal to the closed establishments, that's why the balance of changes is equal to zero.

Both in quantitative (as mentioned above) and in qualitative terms, the greatest percentage of newly opened establishments are concentrated within Lybidska square, but these establishments to the services sector. Therefore, it is necessary to select the part of the Antonovycha St, from the building №155 from to Lybidska square, where the percentage of newly opened establishments is the maximum (excluding Lybidska square). By a general percentage of the changes, this part has undergone major transformations under the influence of the core of the city center. There is enough transformed the territory from the intersection with the Telmana St and to the above-mentioned territory.

\section{Conclusions}

This research demonstrates that real spatial changes have occurred on the territories closest to the core, and almost all spheres of human activity fall under the influence. The most stable are administrative-managerial and educational establishments that at the moment have not experienced any impact, but we cannot confidently say whether they would change over time. The most buildings located close to the nucleus are polyfunctional; the nucleus changes only the prevailing functions. In general, on the researched territory we can see great concentration and constant increase of non-food shops and services, banks and various agencies providing financial legal services. Points providing quick loans to the salary without collateral property are also very widespread here; they are concentrated at points of sale of goods selective demand. This phenomenon can be explained by the financial crisis in the country, difficult material circumstances for living, caused by the military conflict in the east of our country, inflation etc. 


\section{References:}

1. Bìlokon' U. M. Regional'ne planuvannâ (teoriâ ì praktika) [Regional planning (theory and practice)]. Ed. I.O. Fomin. Kyiv, 2003, 246 p. (In Ukrainian).

2. Îsuk S. İ., Gladkij O. V. Kï̈vs'ka gospodars'ka aglomeraciâ: dosvìd regìonal'nogo menedžmentu [Kyiv economic agglomeration: the experience of regional management]. Kyiv, 2005, 239 p. (In Ukrainian).

3. Lybidska square in Holosiivskyi district, Kyiv (view of the mall "Ocean Plaza"). Access mode: http://interesniykiev.livejournal.com/3705813.html

4. View of S. Kovalska RCCP, 2015. Access mode: http://kovalska.com/ua/pat-zavod-zbk-im-svitlani-kovalskoyi

5. View of Demiivka Sugar Refinery, 1975. Access mode: https://www.retroua.com

6. Špačuk E. V. Gorod kak obosoblennaâ territorial'nâ̂ social'no-èkonomičeskâ̂ sistema [The city as a separate territorial socio-economic system]. Author's abstract of PhD Thesis. Kharkiv, 2000, 210 p. (In Russian).

7. Izmeneniâ gorodskogo prostranstva v Ukraine [The change of urban space in Ukraine]. Ed.: L. G. Rudenko. Kyiv, 2013, 160 p. (In Russian).

8. Friedmann J., Goetz W. World City Formation: An Agenda for Research and Action. International Journal of Urban and Regional Research, 1982, Vol. 6 (3), pp. 309-343.

9. Sassen S. The Global City: New York, London, Tokyo. Princeton, 1991.

10. Istoriâ Kieva [The history of Kyiv]. Vol. 2. Executive editor: V. G. Sarbej. Kyiv, 1984, 464 p. (In Russian).

11. Istoriâ Kieva [The history of Kyiv]. Vol. 3: Book 1. Executive editor: N. I. Suprunenko. Kyiv, 1985, 496 p. (In Russian).

12. Muzej istorii goroda Kieva. Fotoputevoditel' [Museum of Kyiv History. Photo-Guide]. Kyiv, 1988, 224 p. (In Russian).

13. Axenov K., Brade I., Bondarchuk E. The transformation of urban space in post-Soviet Russia. Taylor \& Francis, 2006, $196 \mathrm{p}$.

14. Brief information about Moskowskyi district in Kyiv. Access mode: http://geo.ladimir.kiev.ua/pq/dic/a-MOSKOVSKIJ_RAJON (In Russian).

15. Holosiyivskyi district in Kyiv: State Administration. Access mode: http://www.golos.kievcity.gov.ua/content/ menyu-2.html (In Ukrainian). fabrike

16. Brief information about knitting factory "Kyianka". Access mode: http://www.kiyanka.kiev.ua/index.php/o- 